\title{
Methemoglobulinemia due to Dapson Use: A Case Report
}

\author{
Dapson Kullanımına Bağlı Gelişen Methemoglobinemi: Olgu Sunumu
}

Recai Ergün, Serap Atik, Dilek Ergün, Fikret Kanat

\begin{abstract}
Dapson, although generally well tolerated, can lead to hematological side effects. Although methemoglobinemia is a rare clinical condition, it can culminate in death if not treated in a timely and appropriate manner. A 21 -year-old male patient presented to our outpatient clinic with shortness of breath, with oxygen saturation in ambient air measured by pulse oximetry at $88 \%$. His initial medical history and physical examination were unremarkable for possible causes of dyspnea, while arterial blood gas measurements revealed methemoglobin elevation (Fmethb: 10.6). Detailed history revealed that dyspnea with subsequent hypoxia had started after dapsone treatment due to $\lg$ A dermatitis. We present this case report to highlight the possible role of dapsone as a rare cause of hypoxemia and methemoglobinemia, as exemplified in this young patient undergoing dapsone treatment for $\lg A$ dermatitis in which dyspnea was the initial symptom.
\end{abstract}

Key words: Methemoglobinemia, dapson, hypoxemia.

\section{Özet}

Dapson genellikle iyi tolere edilmesine rağmen hematolojik yan etkiler gösterebilmektedir. Methemoglobinemi ender görülen bir klinik durum olmasına karşın, zamanında ve uygun tedavi edilmediği takdirde ölüme neden olabilir. Yirmi bir yaşında erkek hasta nefes darlığı nedeni ile polikliniğimize başvurdu. Oda havasında ölçülen okijen saturasyonu \%88 idi. Öykü, fizik muayene ve tetkiklerinde nefes darlığını açıklayacak bulgu yoktu. Arter kan gazında methemoglobin düzeyi yüksek (Fmethb: 10,6) olarak saptandı. Dispne ve hipoksi bulguları olan hastada ayrıntılı anamnezde IG A Dermatitine bağlı dapson kullanımı olduğu öğrenildi. IG A dermatiti nedeniyle dapson kullanan ve dispne ile başvuran genç hastada hipoksemi ve methemoglobineminin nadir nedenlerinden olan dapson kullanımını akla getirmek adına bu olguyu sunuyoruz.

Anahtar Sözcükler: Methemoglobinemi, dapson, hipoksemi.
Department of Chest Diseases, Selçuk University Faculty of Medicine, Konya, Turkey
Selçuk Üniversitesi Selçuklu Tıp Fakültesi, Göğüs Hastalıkları Anabilim Dalı, Konya

Submitted (Başvuru tarihi): 04.04.2021 Accepted (Kabul tarihi): 08.05.2021

Correspondence (iletişim): Recai Ergün, Department of Chest Diseases, Selçuk University Faculty of Medicine, Konya, Turkey

e-mail: recaiergun@gmail.com 
Hemoglobin $(\mathrm{Hb})$ is an iron-containing molecule (iron in its ferrous form, i.e. $\mathrm{Fe}+2$ ) that is found in erythrocytes and is responsible for carrying oxygen to tissues. Methemoglobinemia results from the oxidation of iron in hemoglobin into its ferric $(\mathrm{Fe}+3)$ form due to oxidative stress. The resultant methemoglobin is reduced by the cytochrome b5 reductase enzyme found in erythrocytes, and the inhibition of this enzyme causes methemoglobinemia. Dapson (4,4-Diaminodiphenylsulphone) is a sulfone antibiotic that inhibits the synthesis of folate and has potent anti-inflammatory effects (1), and is used for the treatment of leprosy, malaria, Pneumocystis jirovecii pneumonia and some other dermatological disorders (2).

We present this case report to remind clinicians of the potential of dapsone to cause methemoglobinemia, exemplified here by a young male patient receiving dapsone for the past 2.5 years due to IgA dermatitis.

\section{CASE}

A consultation was requested from the dermatology unit for a 21 -year-old male patient with dyspnea with no symptoms other than shortness of breath, no reported tachycardia, tachypnea or headache, and no neurological complaints. The patient's medical history revealed a diagnosis of IgA dermatitis dating back 5 years, treated with dapsone (50 mg, q.i.d.) and methylprednisolone (16 $\mathrm{mg}$ o.m.) for the past 2.5 years, but no other disease or drug use history. A physical examination revealed blood pressure: 124/80 mmHg, pulse: 88 beats/minute, respiratory rate: 19/minute, saturation with pulse oximeter: $88 \%$ and fever: $36.5{ }^{\circ} \mathrm{C}$. There was no cyanosis, and chest sounds were normal. The patient was conscious, oriented and cooperative, there was no cyanosis on the skin, or any significant pathological findings in other system examinations, and no significant pathological finding on electrocardiography except sinus tachycardia. Complete blood count, biochemistry panel, D-dimer and collagen disease markers were also normal. A chest $\mathrm{x}$-ray revealed no pathological findings (figure 1), and arterial gas analysis results were as follows: $\mathrm{pH} 7.38, \mathrm{PaCO}_{2}$ $46.6 \mathrm{mmHg}, \mathrm{PaO}_{2} 67.3 \mathrm{mmHg}$, arterial oxygen saturation $88 \%$, lactate $1.6 \mathrm{mmol} / \mathrm{l}$ and methemoglobin (Fmethb) $10.6 \%$.

Furthermore, no clinical or radiological signs suggestive of pulmonary embolisms were detected, and echocardiography, peripheral blood smear and hemoglobin electrophoresis were normal. The family history was negative for hereditary methemoglobinopathy. Due to the lack of other potential causes of methemoglobinemia and high
Fmethb, a diagnosis of drug-related methemoglobinemia was suspected. His ongoing treatment with dapsone was discontinued was monitored, and oxygen inhalation and high dose intravenous ascorbic acid $(2 \mathrm{~g}$ infusion for 3 days) were administered, after which the patient's shortness of breath resolved. Blood pressure was 120/86 $\mathrm{mmHg}$, pulse: $82 / \mathrm{min}$, respiratory rate: $16 / \mathrm{min}$ and saturation measured with pulse oximeter: $96 \%$. The blood gas analysis was as follows: $\mathrm{pH} 7.41, \mathrm{PaCO}_{2} 40.5 \mathrm{mmHg}$, $\mathrm{PaO}_{2} 95.4 \mathrm{mmHg}$, arterial oxygen saturation $97 \%$, lactate $1.6 \mathrm{mmol} / \mathrm{l}$ and methemoglobin (Fmethb) 1.2\%. The patient responded to treatment with a reduction of methemoglobin, and was subsequently discharged.

\section{DISCUSSION}

Dapsone is an aniline derivative belonging to the class of synthetic sulfones with both anti-bacterial and antiinflammatory activities (2).

Although the exact mechanism of action of dapsone in inflammatory disorders is unknown, it has been proposed to inhibit neutrophil chemotaxis and lysosomal enzymes in addition to reducing free oxygen radicals as a result of its antioxidant properties (3). Dapsone is metabolized by the hepatic cytochrome P450 enzymes. The hematological side effects of dapsone, such as hemolytic anemia and methemoglobinemia, have been largely attributed to the potent oxidative effects of its metabolites $(3,4)$. Methemoglobinemia emerges as a result of decreased activity in the enzyme cytochrome $b$ reductase found in erythrocytes (5).

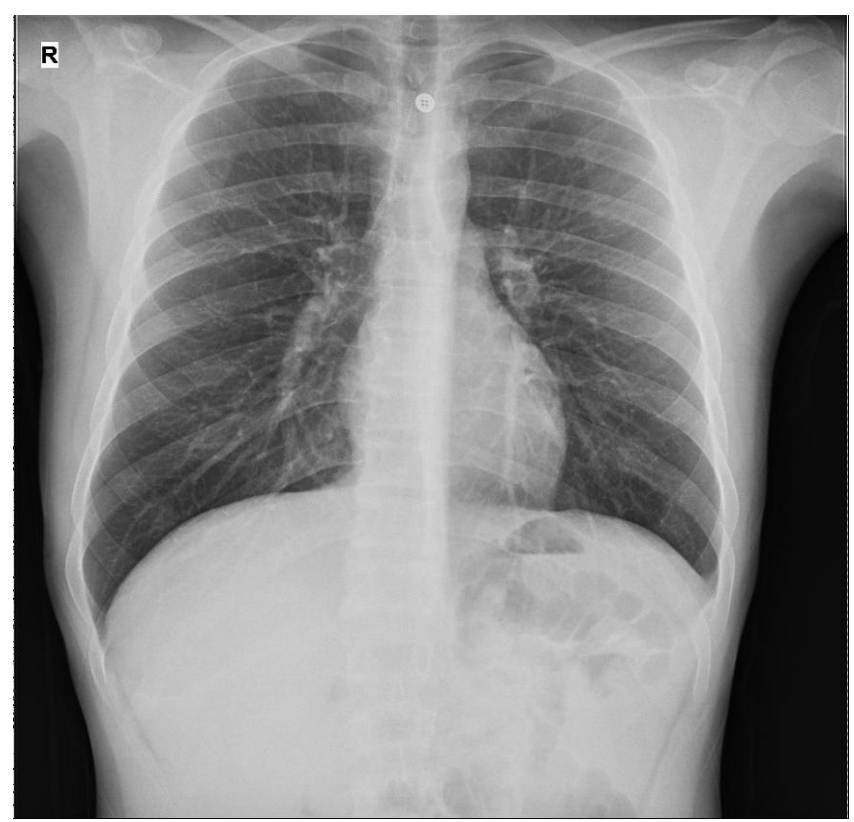

Figure 1: Chest $x$-ray 
Methemoglobin is formed through the oxidation of ferrous iron ( $\mathrm{Fe} 2+$ ) to its ferric form $(\mathrm{Fe} 3+$ ) in the hemoglobin molecule, leading to structural changes, reduced $\mathrm{O} 2$ carrying capacity and the prevention of $\mathrm{O} 2$ supply to tissues. Consequently, a shift in oxygen concentration is observed, and functional anemia develops (6).

Methemoglobinemia may be acquired or hereditary, the former being more common (7). Most cases of acquired methemoglobinemia result from increased methemoglobin production induced by exogenous substances. To date, various chemical molecules and drugs have been reported to be associated with acquired methemoglobinemia, including nitrites, nitrates, chlorates, quinines, aminobenzenes, nitrobenzenes, nitrotolvenes, phenacetine, chloroquine, dapsone, phenytoin, sulfonamides and local anesthetics (2), among which dapsone and local anesthetic agents (benzocaine, lidocaine, prilocaine) represent the most frequent cause of methemoglobinemia Heroin, cocaine and other illicit drugs may cause otherwise unexplained acquired methemoglobinemia $(8,9)$, and nitrates and nitrites, root vegetables such as beetroot and carrots, turnip juice, mushroom poisoning and certain types of frozen foods containing nitrite as a preservative may be potential culprits.

Dapsone, however, is the most frequent cause of methemoglobinemia, representing almost $42 \%$ of all cases in a reported series of 138 patients (10).

Methemoglobinemia should be suspected in patients with cyanosis and hypoxia that are unresponsive to oxygen replacement. The optimum first-line test in suspected cases is a simple blood gas analysis including quantification of methemoglobin levels. Pulse oximetry cannot detect methemoglobinemia and may present falsely normal oxygen levels.

Symptoms may range from mild cyanosis, dyspnea or non-specific manifestations (headache, dizziness, fatigue, nervousness, drowsiness) to shock, severe respiratory depression, or sometimes fatal neurologic impairment (coma, seizures) resulting from tissue hypoxia (7).

Under normal conditions, methemoglobin comprises less than $1 \%$ of the total body hemoglobin $(\mathrm{Hb})$, and when its levels rise, the oxyhemoglobin curve shifts to the left, leading to hypoxia, lactic acidosis and even death in severe cases. Methemoglobinemia is diagnosed when methemoglobin levels exceed 5\% with the emergence of symptoms at levels greater than 10\%. A methemoglobin percentage of $>30 \%$ to $40 \%$ leads to severe symptoms, and is considered a life-threatening condition. A methemoglobin level of $>10 \%$ is associated with cyanosis and skin discoloration, while tachycardia, fatigue, vomiting, nausea and respiratory stress become more marked at levels $>30 \%$. Lethargy, stupor and syncope may be observed at levels of $>55 \%$, and cardiovascular collapse and even death at levels of $\geqslant 70 \%(11,12)$.

A critical initial step in the management of methemoglobinemia is the elimination or discontinuation of the insulting agent. The need for treatment is dependent on the patient's clinical condition and the level of methemoglobin. Appropriate supportive treatments should be given, such as opening an intravenous access route, fluid or vasopressor therapy for hypotension, intubation and mechanical ventilation for respiratory failure, and antiepileptic drugs for seizure. Active treatment is required in individuals with neurological signs or methemoglobin levels of $>30 \%$ using methylene blue, ascorbic acid and riboflavin. Treatment may not be necessary in asymptomatic cases or in those with mild symptoms and methemoglobin levels of $<20 \%(5,12-14)$.

In the presented case, not requesting tests for hereditary methemoglobinemia can be considered a deficiency of the case report.

\section{CONCLUSION}

This case report highlights a potentially serious complication of dapsone treatment. In patients presenting with unexplained dyspnea, the potential for methemoglobinemia and dapsone as a triggering agent should be kept in mind. The first-line treatment should consist of methylene blue, and if this option is unavailable, high dose ascorbic acid should be considered.

\section{CONFLICTS OF INTEREST}

None declared.

\section{AUTHOR CONTRIBUTIONS}

Concept - R.E., S.A., D.E., F.K.; Planning and Design R.E., S.A., D.E., F.K.; Supervision - R.E., S.A., D.E., F.K.; Funding - R.E., S.A., D.E., F.K.; Materials - F.K., S.A., U.K., A.I.; Data Collection and/or Processing - S.A., R.E., D.E.; Analysis and/or Interpretation - R.E., D.E., S.A.; Literature Review - R.E., S.A., D.E.; Writing - R.E., S.A., D.E., F.K.; Critical Review - F.K., R.E.

\section{YAZAR KATKILARI}

Fikir - R.E., S.A., D.E., F.K.; Tasarım ve Dizayn - R.E., S.A., D.E., F.K.; Denetleme - R.E., S.A., D.E., F.K.; Kaynaklar R.E., S.A., D.E., F.K.; Malzemeler - F.K., S.A.; Veri Toplama ve/veya İşleme - S.A., R.E., D.E.; Analiz ve/veya 
Yorum - R.E., D.E., S.A.; Literatür Taraması - R.E., S.A., D.E.; Yazıyı Yazan - R.E., S.A., D.E., F.K.; Eleştirel İnceleme - F.K., R.E.

\section{REFERENCES}

1. Ashurst JV, Wasson MN, Hauger W, Fritz WT. Pathophysiologic mechanisms, diagnosis, and management of dapsone-induced methemoglobinemia. J Am Osteopath Assoc 2010; 110:16-20.

2. Sago J, Hall III RP. Dapsone. Dermatol Ther 2002; 15:340-51. [CrossRef]

3. Wolf R, Matz H, Orion E, Tuzun B, Tuzun Y. Dapsone. Dermatol Online J 2002; 8:2. [CrossRef]

4. Cucinell SA, Israili ZH, Dayton PG. Microsomal Noxidation of dapson as a cause of methemoglobin formation in human red cells. Am J Trop Med Hyg 1972; 21:322-31. [CrossRef]

5. Wright RO, Lewander WJ, Woolf AD. Methemoglobinemia: etiology, pharmacology, and clinical management. Ann Emerg Med 1999; 34:646-56. [CrossRef]

6. Vieira JL, Riveira JG, Martins Ade N, Silva JP, Salgado CG. Methemoglobinemia and dapsone levels in patients with leprosy. Braz J Infect Dis 2010; 14:319-21. [CrossRef]
7. Cortazzo JA, Lichtman AD. Methemoglobinemia: a review and recommendations for management. J Cardiothorac Vasc Anesth 2014; 28:1043-7. [CrossRef]

8. Falkenhahn M, Kannan S, O'Kane M. Unexplained acute severe methaemoglobinaemia in a young adult. $\mathrm{Br} \mathrm{J}$ Anaesth 2001 ; 86:278-80. [CrossRef]

9. McKinney CD, Postiglione KF, Herold DA. Benzocaineadultered street cocaine in association with methemoglobinemia. Clin Chem 1992; 38:596-7. [CrossRef]

10. Ash-Bernal R, Wise R, Wright SM. Acquired methemoglobinemia: a retrospective series of 138 cases at 2 teaching hospitals. Medicine (Baltimore) 2004; 83:265273. [CrossRef]

11. Mansouri A. Methemoglobinemia. Am J Med Sci 1985; 289:200-9. [CrossRef]

12. Coleman MD, Coleman NA. Drug-induced methaemoglobinaemia. Treatment issues. Drug Saf 1996; 14:394405. [CrossRef]

13. Döłsch J, Demirakça S, Kratz M, Repp R, Knerr I, Rascher W. Comparison of methylene blue, riboflavin, and $\mathrm{N}$ acetylcysteine for the reduction of nitric oxide-induced methemoglobinemia. Crit Care Med 2000; 28:958-61. [CrossRef]

14. Park SY, Lee KW, Kang TS. High-dose vitamin C management in dapsone-induced methemoglobinemia. Am J Emerg Med 2014; 32:684.e1-3. [CrossRef] 